段であり，いわば車の両輪である，とりわけ，重要な生 命現象発現の引き金となっている，あるいはそれに関わ っている「もの」を見いだし, 取り出し, さらにはつく り出すに至るまでをきちんと取り扱うには, 分析化学や 有機化学のような「化学」が必須となる. 介在する「も の」がはっきりわかれば, 重要な手がかりとなり, 現象 解明への格段のスピードアップにつながるのは, 過去一 世紀の抗生物質, 動植物ホルモン, 微生物ホルモン, フ エロモンなどの研究成果などからも明らかである.

近年の分離精製技術や機器分析技術における精度の超 高度化は,「もの」の追求を効率化しつつあるが, 現象 に関わる超微量成分の追跡は今後にも残された大きな課 題である，たとえば花芽の形成のように，時間の要素が 入ってくるとさらに状況は複雑で,「もの」の存在の有 無を探る困難さは計り知れない。面白い生命現象に関わ り，未だ日の目を見ていない「もの」が，どこかで我々 を待ち受けているはずである.それらを見いだし，つく り，生物学の手法をも駆使して現象を解明してゆくの が, 次世代のバイオサイエンスの重要な一方向であろ う.これらの研究が応用に結びつけば, まさに農芸化学 的実学の神髄といえよう.「ものとり」,「ものつくり」 はその原点なのである. 生命科学分野を目指す若人が 「生物を見極めるために磨く化学の目」を養うことの面 白さに気づき，「もの」にこだわる研究に大いに興味を 示して貪いたいものである.

今回このような観点から, 連載講座として農学, 生命 科学分野の第一線で面白い「もの」に関わる研究を展開
している 10 研究グループの成果をわかりやすく解説し ていただくこととした. 10 回連載の著者と題目を以下 に示す.ご一読の上, 感想やご批判などいただければ幸 いである.

\section{“「もの」が語るバイオサイエンス”連載予定}

1. ものつくりが目指すバイオサイエンス：機能解析と有用 物質創製を指向して

渡邊秀典，石神 健，北原 武 (東大農)

2. 発光物質が語るバイオサイエンス

金久保暁，久世雅樹，磯部 稔 (名大農)

3. ジアステレオマー法の本質的と考えられていた問題点を 克服した超高感度遠隔位不斉識別法の開発とその生理活 性天然物の絶対構造式決定への応用

大類 洋, 赤坂和昭, 今泉啓一郎（東北大生命科学）

4. アミノグリコシド抗生物質の生合成：分子レベルでの解 明柿沼勝己，為我井秀行（東工大生命理工）

5. 生物活性ジテルペンの酵素的生産を目指して：DNA ポ リメラーゼ $\alpha$ 特異的阻害剤 aphidicolin の酵素的全合 成研究及川英秋 (北大農), 佐々武史 (山形大農)

6. ペプチド合成によるホルボールエステル受容体の機能解 析

大東 肇, 入江一浩（京大農）

7. モノづくりの基盤としての有機合成反応：酵素触媒を例 として 須貝 威, 鈴木麻珠三, 冨宿賢一 (慶大理工)

8. 天然物と計算科学そしてゲノム科学との接点: ディスプ レイクローニング法の理想と現実

菅原二三男（東理大理工）

9. 農業生産性の向上を目指す天然生物活性物質の化学合成 桑原重文 (東北大農)

10. バイオミネラルの科学 長澤宽道 (東大農)

\title{
ものつくりが目指すバイオサイエンス 機能解析と有用物質創製を指向して
}

\section{渡邊秀典，石神 健，北原 武 \\ 東京大学大学院農学生命科学研究科}

生命科学・天然物化学の領域で「ものつくり(=有機 合成化学)」の意義として考えられるのは, (1)構造の決 定や確認, 訂正, (2)試料の供給, (3)機能解析や構造活性 相関研究のための類縁体や標識体の提供, (4)有用物質創
製，などが挙げられる．特に，生命現象が分子レベルて の情報伝達で説明されるようになってきた昨今, 有機合 成化学が生化学者や生理学者といかに連携し, どのよう な形で生命科学分野と関わりながら成果を生み出してい 
けるかは，生命科学分野の重要なテーマの一つである. 本稿では筆者らの最近の研究成果の中から,「ものつく り」を通して, 提出構造を訂正し, 実用化やさらなる生 化学的研究に向けて発展しつつあるもの, 標識分子やそ の部位の特定などに役立ったものなどについて実例を挙 げて紹介したい。

\section{合成による立体構造の解明}

\section{1. 抗コクシジウム活性を有するフデカロン}

Eimeria 属の原虫によってひき起こされるニワトリ のコクシジウム症は, 養鷄産業にとって時に壊滅的な 打撃を与える脅威であるが，これまで抗コクシジウム剤 として使われてきたモネンシンに対して耐性をもった Eimeria 属の出現が近年問題化している. フデカロン (Fudecalone) は，1995年大村らにより Penicillium sp. FO-2030より単離・構造決定された抗コクシジウム 活性をもつセスキテルペンで，モネンシン耐性の Eimeria tenellaに対してもシゾント（分裂体）形成を 阻害すると報告されている(1).この構造決定は主として NMR (nuclear magnetic resonance) によってなさ れ, NOE (nuclear Overhauser effect) 解析からその 立体配座は図 1-A であると推定されたことから 1a の立 体構造が提出された。

筆者らは既知化合物のバーチ還元とそれに引き続くア ルキル化 $(2 \rightarrow 3)$ と環化反応 $(4 \rightarrow 5)$ を用いて骨格を構築 し，短工程でフデカロンの合成を行なった。しかし得ら
れた化合物 $1 \mathrm{~b}$ は，へミアセタール性水酸基に関するジ アステレオマー混合物で，さらにNMRで観測された 両異性体はともに天然物と一致しなかった。また, $\mathrm{NOE}$ 実験から，筆者らの合成した $\mathbf{1 b}$ は，提出構造 $\mathbf{A}$ の配座異性体 B であることがわかった ${ }^{(2)}$.

もしフデカロンの cis に縮合したオクタロン骨格の立 体配座が，5 員環ラクトールの存在のために相互変換し づらくなって $\mathbf{A}$ と B が別個に存在しているとすれば, 大変希有な例で興味深い.そこで $1 \mathrm{~b}$ から 6 を調製し た。この段階で立体配座が図 1 で示した通り $\mathbf{A}$ タイプ であることを確認した後，セレニドの酸化的脱離を行な った。この脱離反応は低温下で行なえるので，もし $\mathbf{A}$ と $\mathbf{B}$ が別個に存在しうるのならば，得られるものは $\mathbf{A}$ タイプの配座異性体であるはずである.

しかし，得られた 7 は B タイプに配座が変わってい た。このことから，当初推定していた天然物の立体化学 は構造決定の際に何らかの誤りがあったものと判断し, 立体異性体の合成を行なうこととした，種々検討した結 果，5 から 8，9 を経由して trans-オクタロンへと異性 化した 1c が天然物と一致することがわかった ${ }^{(3)}$. また, 中間体の光学分割によって両鏡像体を合成し，天然物は 1cに示した絶対立体配置であることを明らかにするこ とができた．改訂構造の $1 \mathrm{c}$ は in vitro で良好な生物活 性を示したため，現在は実際にニワトリの雛に対する投 与実験で抗コクシジウム活性評価をすべく，1c ならび にいくつかの類縁体の大量合成を行なっている.
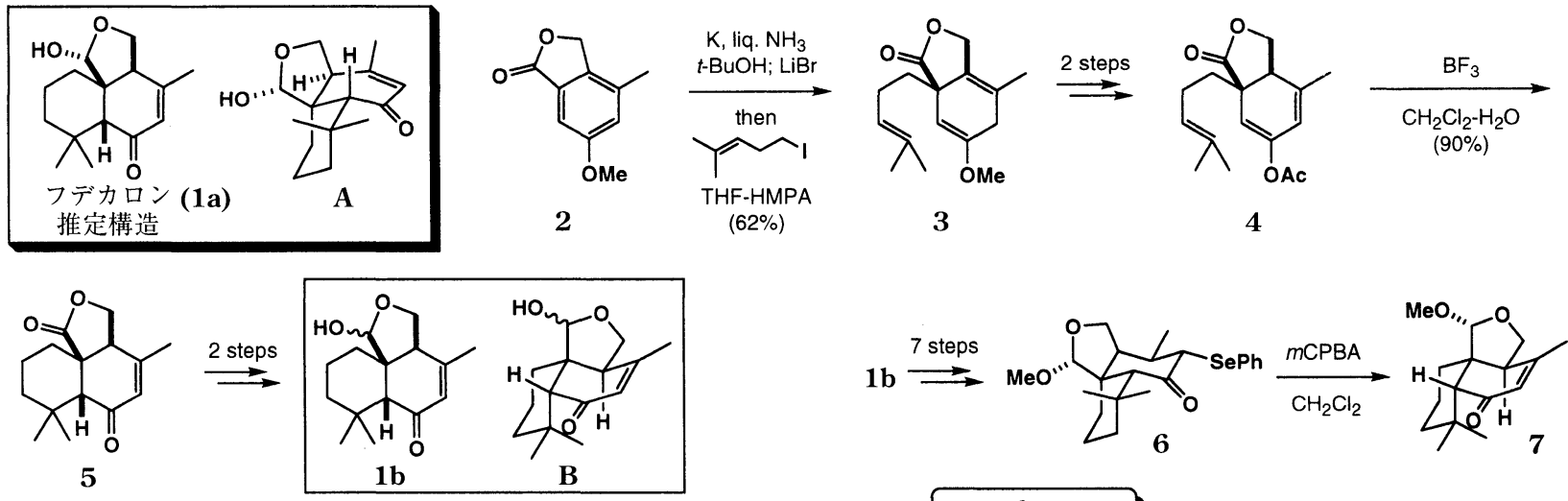

5

$1 \mathrm{~b}$
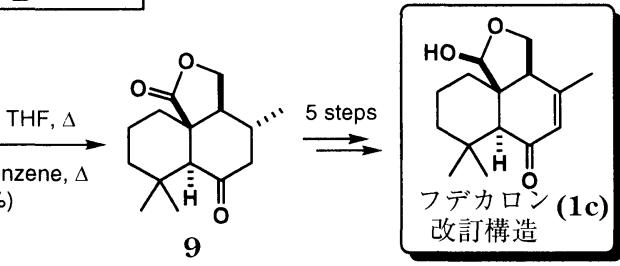

図 1 ロフデカロンの合成と立体配置の改訂 


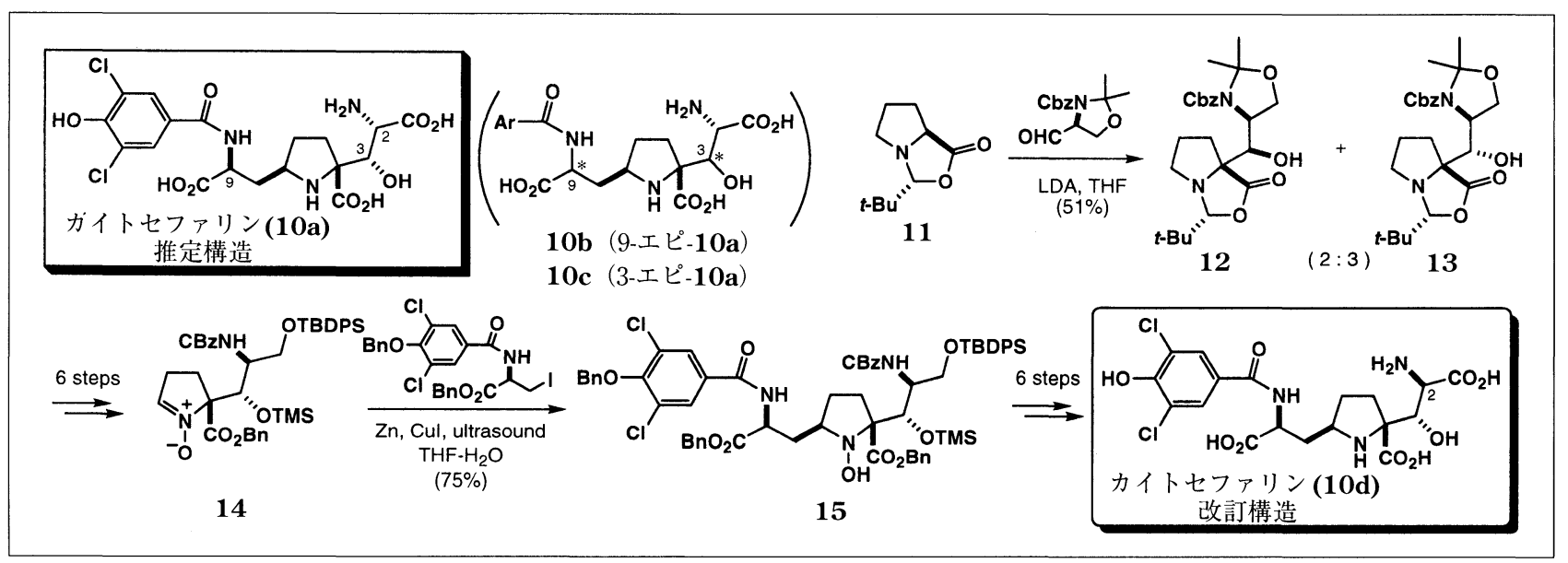

図 2 ・ カイセファリンの合成と立体配置の改訂

\section{2. 神経細胞保護活性物質カイトセファリン}

脳溢血などに引き続く遅発的な虚血性脳神経細胞死 は，グルタミン酸の過剰放出によってひき起こされるこ とが知られている。そのため脳溢血などの際に後遺症を 最小限にくい止めるための処置薬として, グルタミン酸 レセプターのアンタゴニストの研究が近年活発になされ ている.

カイトセファリン (Kaitocephalin, 図 2-10a) は 1997 年瀬戸，新家らにより，Eupenicillium shearii PF1191 株の固体培地より単離・構造決定された ${ }^{(4,5)}$.こ れは，N-メチル-D-アスパラギン酸 (NMDA) に感受性 の NMDA 型, $\alpha$-アミノ-3-ヒドロキシ-4-イソキサゾー ルプロピオン酸 (AMPA) あるいはカイニン酸 $(\mathrm{KA}) に$ 感受性の AMPA/KA 型の両グルタミン酸レセプターに 対し，強力なアンタゴニスト活性を示す. AMPA/KA 型レセプターに対するアンタゴニスト活性物質が天然よ り見いだされたのは初めてであり，また，従来 NMDA 型レセプターと AMPA/KA 型レセプターのアンタゴニ ストを併用すると, 神経細胞保護に相乗効果が見られる ことから, 両レセプターにアンタゴニストとして働くカ イトセファリンは, 今後の研究成果が期待されている化 合物である。しかし 10a は生産量が不安定で培養による 入手が困難であったため, 各種生化学的研究や構造活性 相関研究に供することを目的として合成研究を開始し た。

ところがこの化合物もまた，合成してみると提出構造 の $10 \mathrm{a}$ は天然物と各種データが一致しなかった.そこ で，10aの 9-エピ体である 10b や3-エピ体の 10c も合 成したが，やはり天然物とは一致しなかった ${ }^{(6)}$.こうな ると手当たり次第に立体異性体を作っていくのが一つの 手ではあるが，幸いにも筆者らは合成研究と並行して構

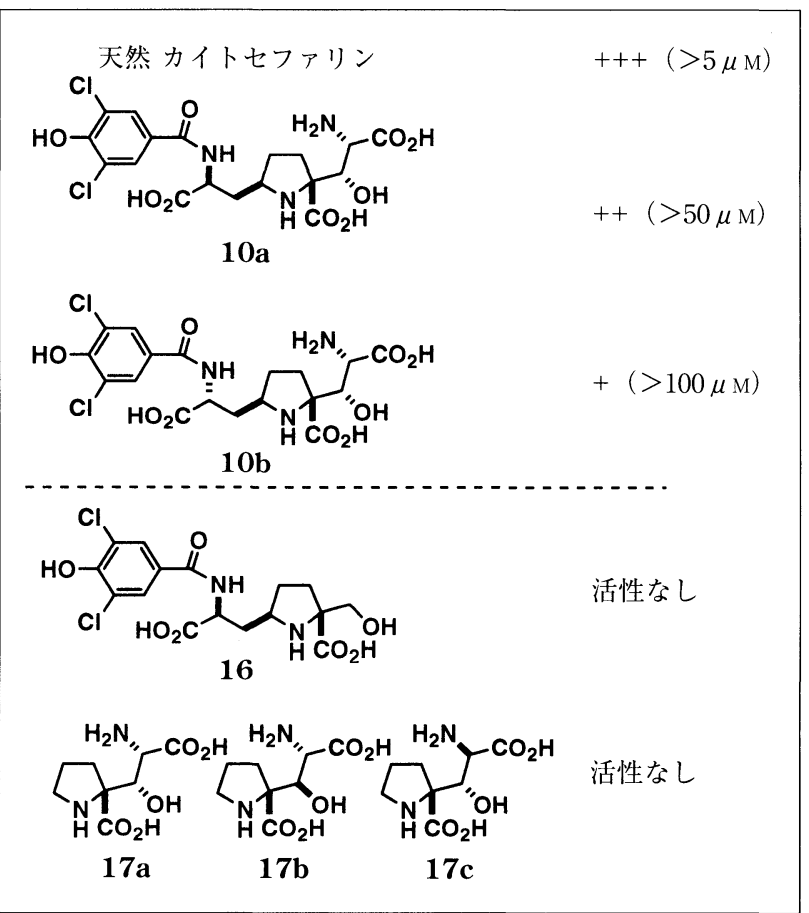

図 3 -合成したカイトセファリン類緑体と光の生物活性

造活性相関研究のために単純化した化合物（図 3-16, $17 \mathbf{a} \sim \mathbf{c})$ も調製していた。このうち，17cのみ ${ }^{1} \mathrm{H}-\mathrm{NMR}$ の C-2, 3 位の化学シフトと結合定数が天然物と非常に 近かったため, 天然物の立体配置は10dではないかと 考え，これを図 2 で示す経路で合成した。鍵反応は 14 から 15 への超音波を用いたヨウ化物のニトロンへの新 規付加反応である. 得られた 10d は, NMR デー夕, 高 速液体クロマトグラフィー (HPLC)の保持時間ともに天 然物と一致し，カイトセファリンの立体構造を明らかに することができた ${ }^{(7)}$.

ただ残念なことに，カイトセファリンはこれまでの培 
養法でまったく得られなくなったため，サンプルの供給 は化学合成によらざるを得なくなってしまったそそのた め, グラム単位での合成と, グルタミン酸レセプターと の結合様式解明のためのプローブ調製を目指し，現在合 成経路の改良を行なっている.

\section{細胞周期阻害物質の合成と機能解析}

1. プリュッシンの合成と構造活性相関

プリュッシン (Preussin, 図 4-18) は1988 年, Asper gillus ochraceus ATCC 22947 ならびに Preussia sp. の培養液から抗真菌および抗菌活性物質として単離され た化合物であるが(8)，最近吉田らにより，細胞周期阻害 活性物質として再発見された ${ }^{(9)}$.これを図 4 上に示した ように，L-フェニルアラニンより得られる 19 に対する

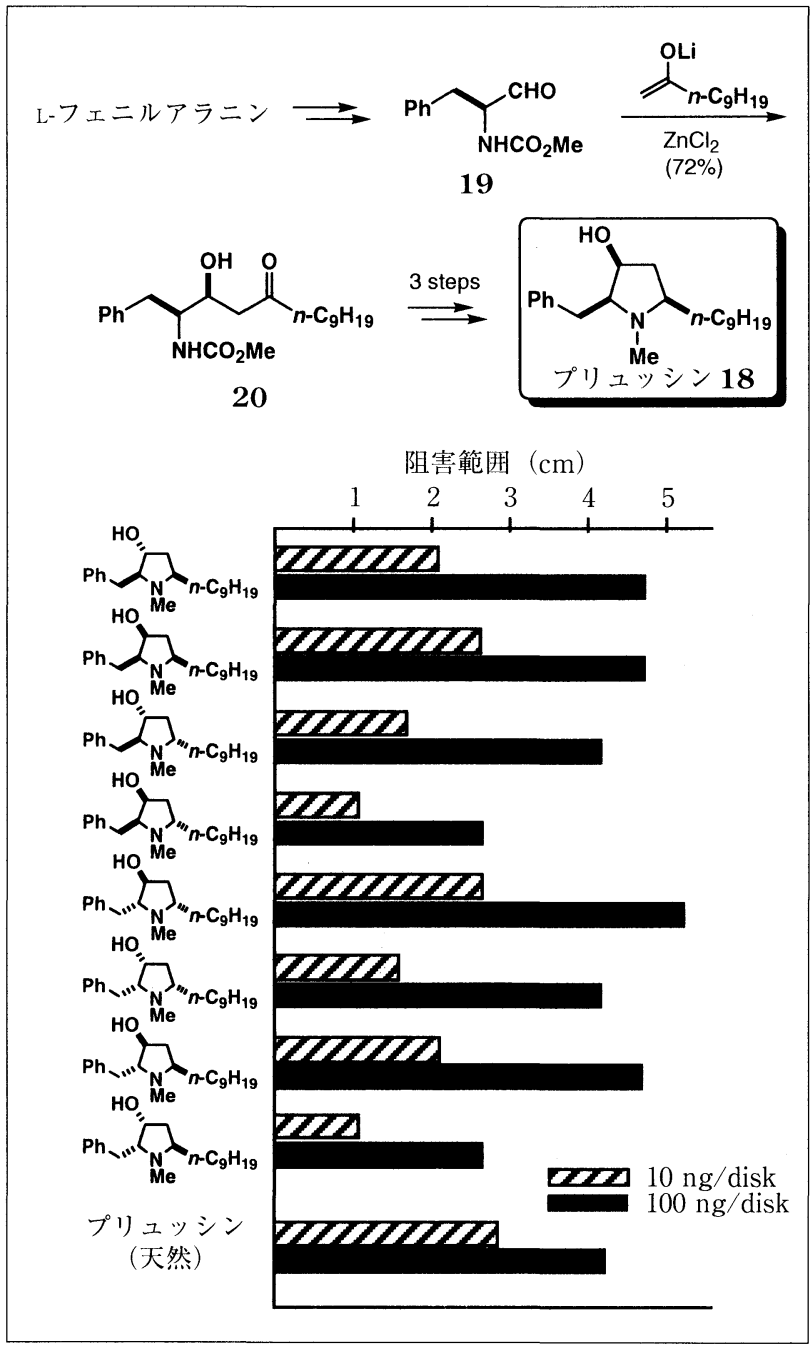

図 4 ロプリュッシン(18)の合成と 8 立体異性体の生物活性 試験の結果

グラフは分裂酵母 $c d c$ 変異株の生育阻止円の大きさを示す.
アルドール縮合と，得られた 20 に還元的ピロリジン環 形成を立体選択的に行なうことにより，短工程で立体選 択的に合成した(10). また，フェニルアラニンの両鏡像 体から出発し，ほほ同様の合成経路であるがアルドール 縮合と環化反応を非立体選択的に行ない，その後ジアス テレオマーを分離することで，プリュッシンがもつ $8 つ$ の立体異性体すべてを得た ${ }^{(11)}$ 。これらの生物活性を調 べたところ，大変興味深いことに，8 異性体すべてが同 程度の活性を示すことが明らかになった(図 4 下).

2. ラディシコールの構造活性相関とプローブ合成によ る結合タンパク質の同定

ラディシコール（Radicicol，図 5-21) は 1953 年に抗 カビ剤として単離され ${ }^{(12)}, 1992$ 年に堀之内, 吉田らに より癌細胞の形態正常化を誘導する化合物として再発見

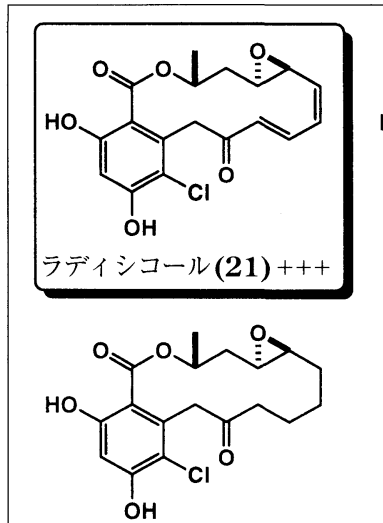

$23++$

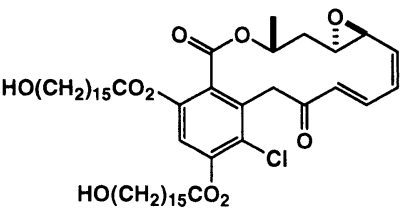

$22+++$<smiles>COC(C)(C)C[C@H](O)CCCCCC(=O)Cc1c(Cl)c(O)cc(O)c1C(=O)O</smiles>

$24 \pm$ ビオチン化プローブ
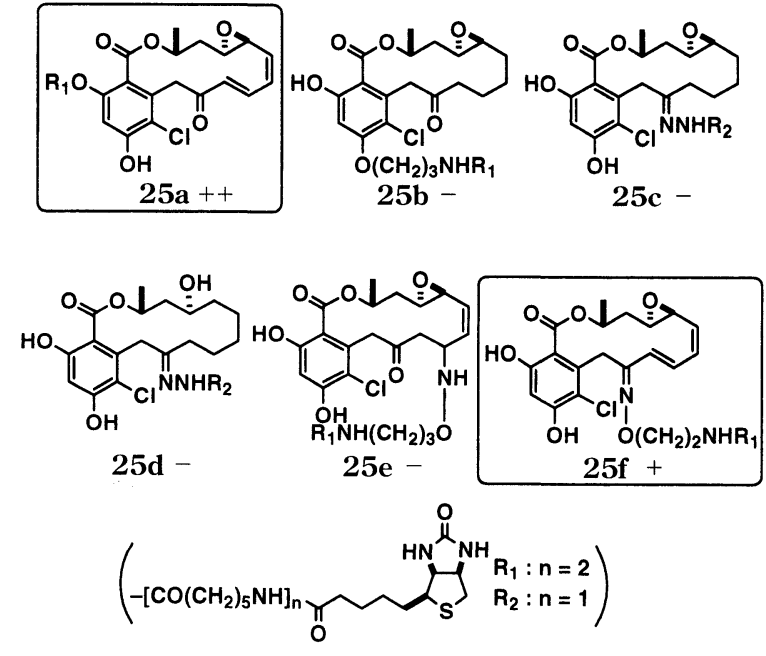

図 5 ・ラディシコール(21)および合成した誘導体の構造と 生物活性

化合物番号横の+, 一は, $\mathrm{v}-s r c$ トランスフォーム細胞の形態正常 化に対する相対的活性強度を示す。 
された，カビの 2 次代謝産物である(13).その後， $\mathrm{G}_{1}$, $\mathrm{G}_{2}$ 期での細胞周期の停止，Srcチロシンキナーゼの阻 害，Ras シグナル伝達経路の阻害など，様々な活性をも つことがわかり関心を集めている(14).

筆者らは活性発現機構解明を目的とし，ビオチン標識 したプローブ合成を行ない，標的タンパク質を同定しよ うと考えた。まずビオチン修飾が可能な部位を探るべ く, 各種誘導体を合成し, 活性試験を行なった(図 5)。 2 つのフェノール性水酸基をアシル化した 22 はラディ シコールと同等の活性，二重結合を還元した 23 は約半 分の活性を示したが，23 から得たアルコール24では活 性が消失したことから，エポキシド部位が活性に強く関 与していることがわかった。

ビオチン化可能な部位として，2つのフェノール性水 酸基とジエノン部位を考え，ビオチン化誘導体 $25 \mathbf{a} \sim \mathbf{f}$ を合成した。これらのうち $25 \mathrm{~b} \sim \mathrm{e}$ はまったく活性を示 さなかったが，25a と 25f はラディシコールよりは弱い ながらも活性を保持していた。また 25a〜fを用い, HeLa 細胞抽出液からの結合タンパク質を SDS-PAGE により解析した(図 6)。その結果，不活性の $25 \mathrm{~b} \sim \mathrm{e} て ゙$ は結合タンパク質は検出されなかったが，25a と25f は それぞれ $120 \mathrm{kDa}, 90 \mathrm{kDa}$ のタンパク質との結合が検 出された。9 $90 \mathrm{kDa}$ のンパク質はこれまでラディシコ

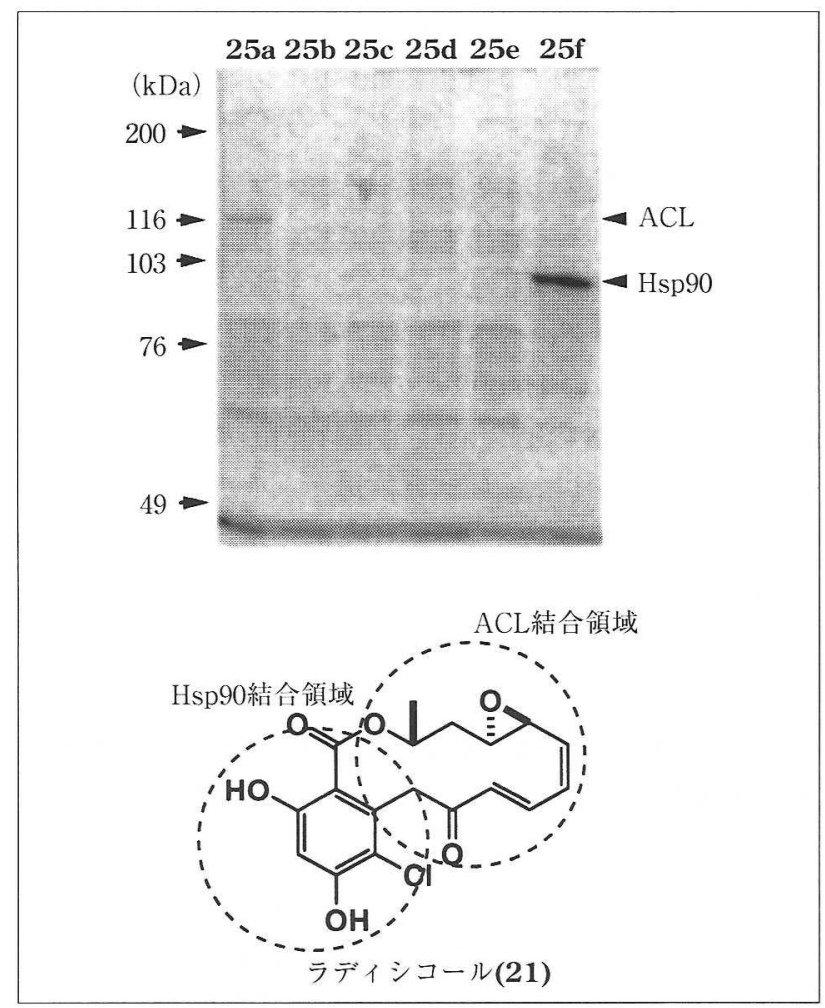

図 6 日ビオチン化プローブを用いたラディシコール(21)の 結合タンパク質のスクリーニングと光の結合部位

SDS-PAGEの染色は Coomassi Brilliant Blueによる. 資料提 供：理化学研究所吉田 稔博士。

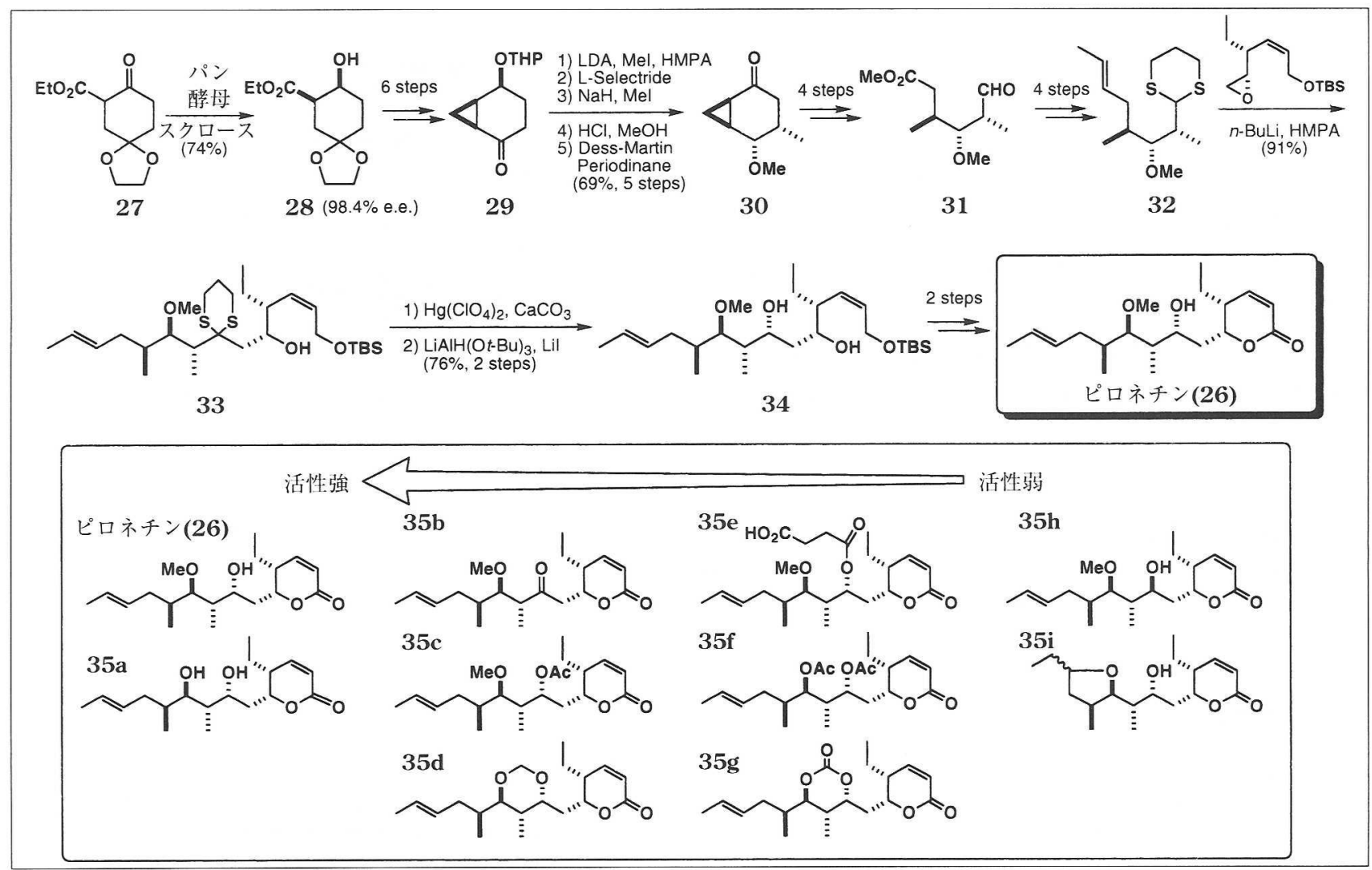

図 7 ロピロネチン(26) の合成と調製した類緑体の生物活性 
ールと結合することがわかっていた Hsp (heat shock protein) 90 であり ${ }^{(15)}, 120 \mathrm{kDa}$ のタンハク質はATP citrate lyase (ACL)で，ラディシコールが $2 つ$ 結合 タンパク質をもつことが示唆された. また, ラディシコ ールは ACLに直接結合することにより ACL 活性を阻 害することも明らかになった ${ }^{(16)}$ ささらに 25a と $25 \mathrm{f}$ は それぞれ他方のタンパク質と結合していないことから， ラディシコールの Hsp90への結合にはフェノール性水 酸基が, ACLへの結合にはケトン部位が重要な役割を 果たしている，すなわちラディシコールが異なる $2 つ の$ タンパク質結合部位をもつことが示唆された. Hsp90 に加え ACL も阻害することが，ラディシコールが様久 な活性をもつ理由であると考えられる。

\section{3. ピロネチンの合成, 構造活性相関とプローブ合成に}

\section{よる機能解析}

ピロネチン (Pironetin, PA-48153C, 図 7-26) は 2 つの異なったグループにより, Streptomyces 属の菌よ り単離・構造決定された化合物で, 植物伸長阻害 ${ }^{(17)}$, 免疫抑制 ${ }^{(18)}$ という異なった活性を示す興味深い化合物 である。また，免疫抑制活性に関しては， T 細胞や B 細胞に作用し, シクロスポリン, FK-506 とは異なった 作用機作をもっている点で関心を集めている ${ }^{(18 b)}$. また 最近，これが微小管重合を阻害することで活性が発現す ることも明らかになっている(19).

26 を図 7 に示すようにして合成した ${ }^{(20)}$. 本合成のポ イントは, パン酵母還元で得られる光学活性な 28 から 出発したこと, 29 の二環性構造を利用して 3 連続不斉 中心の立体制御をしたこと $(29 \rightarrow 30)$, ジチアンのエポ キシド開環によって収斂的に全炭素骨格を構築したこと $(32 \rightarrow 33)$ である.

またピロネチン自体やその合成中間体から $35 \mathbf{a} \sim \mathbf{i}$ の 類縁体を調製し, 構造活性相関を調べた. $\mathrm{G}_{2} / \mathrm{M}$ 期進行 阻害活性，in situ微小管ネットワーク消失活性，in vitro 微小管重合阻害活性の評価を行なったが, 各類縁 体の活性強度はいずれの試験でもほほ同様の傾向を示し た $(\text { 図 7 })^{(21)}$.ここで興味深いのは，側鎖水酸基はアシル 化やケトンへの酸化を受けてもそれほど大きくは活性が 低下しないにもかかわらず(35b，35c および 35e)，立

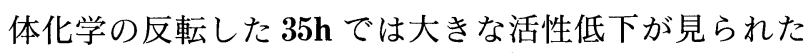
ことである。

構造活性相関研究によって側鎖水酸基をアシル化して も活性にさほどの影響がないことがわかったので，図 8-36 のようなビオチン標識体を合成した.このプロー ブを用いて，ピロネチンの不飽和ラクトン部分が $\alpha$-チ ユーブリンと共有結合を形成することによって微小管重 合を阻害することが明らかになった。このことは, $\beta$-チ ューブリンと結合するビンブラスチンやタキソール，コ ルヒチンとは異なる新しい阻害様式である.

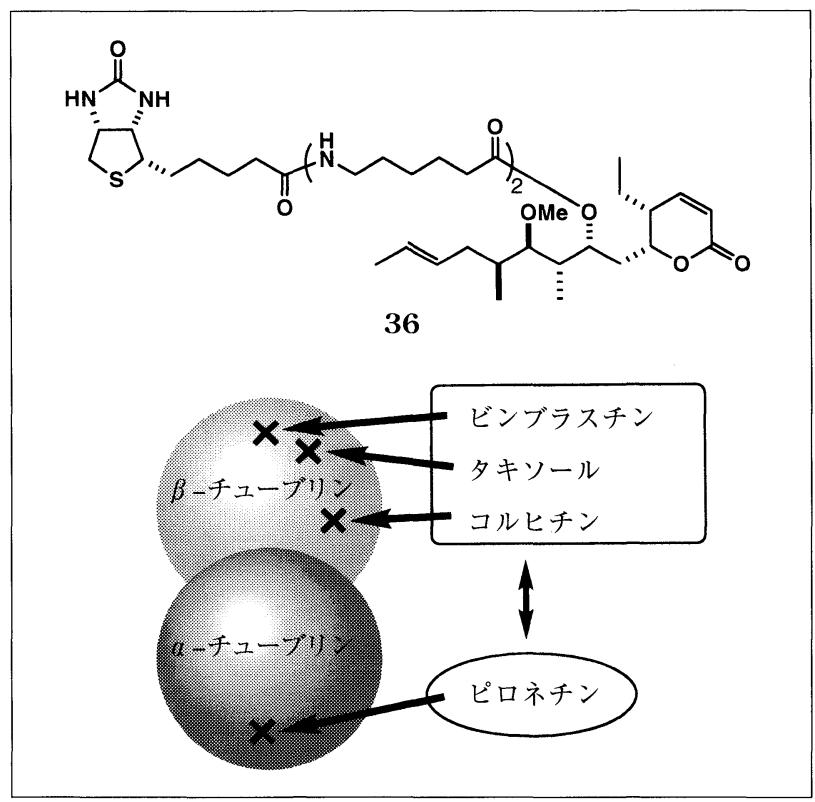

図 8 ロピロネチン (36) は $\alpha$-チューブリンに結合する

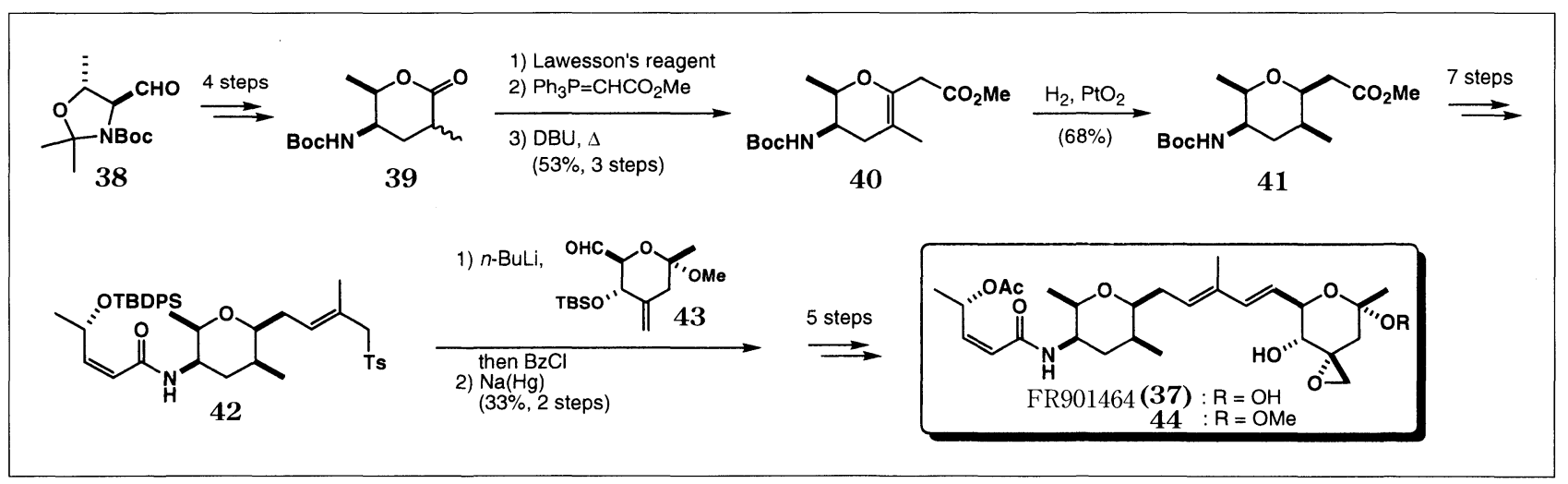

図 9 - FR901464(37) の合成 


\section{FR901464の合成, 構造活性相関とプローブ合成に よる機能解析}

FR901464(図 9-37) は 1996 年, 中島らによりPseudomonas 属の菌より単離・構造決定された ${ }^{(22)}$.これは細 胞転写調節, 細胞周期阻害, クロマチン機能調節などの 様々な作用をもち, 強力な抗癌活性を示す. FR901464 は 2 つのテトラヒドロフラン環がジエン鎖でつながったユ ニークな構造をしており, どの部位が活性発現にどのよ うに関わっているのかに興味がもたれる.

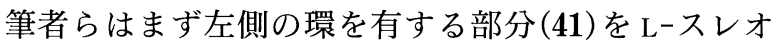
ニンから出発して立体選択的に構築した。これをスルホ ン(42)とした後，2-デオキシグルコースから誘導した右 側環部分 (43) とカップリングさせ合成を達成した ${ }^{(23)}$.

いくつかの合成中間体について, FR901464ととも に生物活性試験を行なったところ，面白いことに 1 段階 前の合成中間体であるメチルアセタール (44)のほうが, FR901464(37)そのものよりも数倍高活性であった。 こ れはアセタールを形成することで右側テトラヒドロフラ ン環の安定性が向上したためと考えている。この知見を もとにビオチン標識したプローブを合成し，標的タンパ ク質の同定，機能解析が進行中である．その結果もいず れ公表する予定だが，大変興味深い知見が得られつつあ る.

*

以上，「ものつくり屋」である筆者らが天然物合成を 通じて，生命科学の領域でどのような形の貢献ができる かを, 最近の筆者らの研究例を挙げて述べてきた。生命 現象に「もの」が関わり，それが生命現象を解き明かす 鍵となるとき，「ものつくり」は不可欠の手法となる. しかしそれは, 生物学者, 生化学・生理学者との連携が あって初めて意味をもち, 成果へとつながってゆく. 今 後の生命科学の発展には, 物理化学者などさらに他分野 の研究者を巻き込んでの連携プレーが必要となってくる であろう。いずれにしても筆者らのつくる「もの」が新 たな研究領域を切り拓くブレークスルーになってくれれ

ば,こんなに幸せなことはない。

謝辞：本稿で述べた研究成果のうち, 特に生物活性試験やプロー ブを用いた標的分子の解明に関する部分は下記の先生方との共同 研究で得られたものであり，この場を借りて心から感謝いたしま す. 東北大学大学院農学研究科中井 裕教授(フデカロン), 東京 大学分子細胞生物学研究所瀬戸治男名誉教授, 新家一男博士(力 イトセファリン), 東京大学大学院農学生命科学研究科堀之内末 治教授ならびに理化学研究所吉田 稔主任研究員(プリュッシン, ラディシコール, FR901464), 横浜市立大学大学院総合理学研究 科笠原浩司博士(プリュッシン), 理化学研究所長田裕之主任研究 員, 兒井健郎博士(ピロネチン).
文献

1) N. Tabata, H. Tomoda, R. Masuda, Y. Iwai \& S. Ōmura: J. Antibiot., 48, 53 (1995).

2) H. Watanabe, T. Furuuchi, T. Yamaguchi \& $T$. Kitahara: Organic Lett., 1, 1079 (1999).

3) H. Watanabe, T. Yamaguchi, T. Furuuchi \& $T$. Kitahara : Tetrahedron Lett., 42, 917 (2001).

4) K. Shin-ya, J.-S. Kim, K. Furihata, Y. Hayakawa \& H. Seto : Tetrahedron Lett., 38, 7079 (1997).

5) H. Kobayashi, K. Shin-ya, K. Furihata, Y. Hayakawa \& H. Seto: Tetrahedron Lett., 42, 4021 (2001).

6) M. Okue, H. Kobayashi, K. Shin-ya, K. Furihata, Y. Hayakawa, H. Seto, H. Watanabe \& T. Kitahara : Tetrahedron Lett., 43, 857 (2002).

7) H. Watanabe, M. Okue, H. Kobayashi \& T. Kitahara : Tetrahedron Lett., 43, 861 (2002).

8) a) R. E. Schwartz, J. Liesch, O. Hensens, L. Zitano, S. Honeycutt, G. Garrity, R. A. Fromtling, J. Onishi \& R. Monaghan : J. Antibiot., 41, 1774 (1988) ; b) J.H. Johnson, D.W. Phillipson \& A.D. Kahle : J. Antibiot., 42, 1184 (1989).

9) K. Kasahara, M. Yoshida, J. Eishima, K. Takesako, T. Beppu \& S. Horinouchi : J. Antibiot., 50, 267 (1997).

10) M. Okue, H. Watanabe \& T. Kitahara: Tetrahedron, 57, 4107 (2001).

11) M. Okue, H. Watanabe, K. Kasahara, M. Yoshida, S. Horinouchi \& T. Kitahara : Biosci. Biotechnol. Biochem., 66, 1093 (2002).

12) P. Delmotte \& J. Delmotte-Plaquee : Nature, 171, 344 (1953).

13) a) H. J. Kwon, M. Yoshida, K. Abe, S. Horinouchi \& T. Beppu : Biosci. Biotechnol. Biochem., 56, 538 (1992) ; b) H. J. Kwon, M. Yoshida, Y. Fukui, S. Horinouchi \& T. Beppu : Cancer Res., 52, 6926 (1992).

14) a) S. Soga, T. Kozawa, H. Narumi, S. Akinaga, K. Irie, K. Matsumoto, S.V. Sharma, H. Nakano, T. Mizukami \& M. Hara : J. Biol. Chem., 273, 822 (1998) ; b) S.W. Ki, K. Kasahara, H. J. Kwon, J. Eishima, K. Takesako, J.A. Cooper, M. Yoshida \& S. Horinouchi : J. Antibiot., 51, 936 (1998).

15) a) T.W. Schulte, S. Akinaga, S. Soga, W. Sullivan, B. Stensgard, D. Toft \& L.M. Neckers : Cell Stress Chaperones, 3, 100 (1998) ; b) S.V. Sharma, T. Agatsuma \& H. Nakano: Oncogene, 16, 2639 (1998).

16) a) S.W. Ki, K. Ishigami, T. Kitahara, K. Kasahara, M. Yoshida \& S. Horinouchi : J. Biol. Chem., 275, 39231 (2000) ; b) S.W. Ki, K. Kasahara, H.J. Kwon, K. Ishigami, T. Kitahara, T. Beppu, M. Yoshida \& S. Horinouchi : Biosci. Biotechnol. Biochem., 56, 538 (1992).

17) a) S. Kobayashi, K. Tsuchiya, T. Harade, M. Nishide, T. Kurokawa, T. Nakagawa \& N. Shimada : J. Antibiot., 47 697 (1994) ; b) S. Kobayashi, K. Tsuchiya, T. Kurokawa, T. Nakagawa \& N. Shimada: J. Antibiot., 47, 703 (1994) ; c) S. Kobayashi, K. Tsuchiya, M. Nishide, T. Nishikiori, T. Nakagawa \& N. Shimada : J. Antibiot., 48, 893 (1995) ; d) K. Tsuchiya, S. Kobayashi, T. Nishikiori, T. Nakagawa \& K. Tatsuta: J. Antibiot., 50, 259 (1997).

18) a) T. Yoshida, K. Koizumi \& H. Itazaki : Japan Patent Kokai, 5-310726, 1993 ; b) K. Yasui, Y. Tamura, T. Nakatani, I. Horibe, K. Kawada, K. Koizumi, R. Suzuki \& M. Ohtani : J. Antibiot., 49, 173 (1996).

19) M. Kondoh, T. Usui, S. Kobayashi, K. Tsuchiya, K. 
Nishikawa, T. Nishikiori, T. Mayumi \& H. Osada : Cancer Lett., 126, 29 (1998).

20) a) H. Watanabe, H. Watanabe \& T. Kitahara: Tetrahedron Lett., 39, 8313 (1998) ; b) H. Watanabe, H. Watanabe, M. Bando, M. Kido \& T. Kitahara : Tetrahedron, 55, 9755 (1999).

21) H. Watanabe, H. Watanabe, T. Usui, M. Kondoh, H. Osada \& T. Kitahara : J. Antibiot., 53, 540 (2000).
22) a) H. Nakajima, B. Sato, T. Fujita, S. Takase, H. Terano \& M. Okuhara : J. Antibiot., 49, 1196 (1996) ; b) H. Nakajima, Y. Hori, H. Terano, M. Okuhara, T. Manda, S. Matsumoto \& K. Shimomura: J. Antibiot., 49, 1204 (1996).

23) M. Horigome, H. Motoyoshi, H. Watanabe \& T. Kitahara : Tetrahedron Lett., 42, 8207 (2001).

\section{プロフィル}

福田 亘博（Nobuhiro Fukuda） 昭和 21 年 2 月 28 日生 $<$ 略歴 $>$ 昭和 47 年琉 球大学農学部農芸化学科卒業 $/ 53$ 年九 州大学大学院農学研究科博士課程食糧化 学工学専攻修了/同年日本学術振興会奨 励研究員 $/$ 同年琉球大学農学部助手 $/ 59$ 年同助教授/平成元年宮崎大学農学部助 教授 $/ 6$ 年同教授，現在にいたる。この 間, 昭和 55〜56 年米国オクラホマ州オク ラホマ医学研究所研究員. 昭和 53 年農博 (九州大学) <研究テーマと抱負 $>$ 現在ま で，ラット肝臟灌流法あるいは肝細胞培 養系を用いて「リポタンパク質の産生と 調節」について，脂肪酸代謝に影響を及 ぼす食事成分や薬剤の面から研究を行な ってきた，最近は，食品成分の中で薬剤 と同等の肝臟脂肪酸代謝に影響を及ぼす 食品成分をいくつか見つけ，それについ て興味をもって研究しているく趣味〉テ ニス，クラシック音楽

畺山 滋志 (Shigeyuki Mayama) 昭和 19 年 4 月 25 日生 <略歴>昭和 43 年京 都大学農学部農林生物学科卒業 $/ 45$ 年 同大学大学院農学研究科修士課程修了／ 48 年米国南イリノイ大学大学院生命科 学研究科博士課程修了 (Ph.D.) 後, 現在, 神戸大学農学部教授, 現在にいたる. 昭 和 58 年農博 (京都大学) <研究テーマと 抱負 $>$ 植物の感染防御応答機構の解明, 根内共生細菌について<趣味>音楽鑑賞

馬 原 淳 (Atsushi Mahara) 昭和 49 年 7 月 23 日生 $<$ 略歴>平成 10 年京都工 芸繊維大学繊維学部高分子学科卒業 $/ 12$ 年同大学大学院工芸科学研究科博士前期
課程高分子学専攻修了 $/ 15$ 年同博士後 期課程機能科学専攻修了見込, 現在にい たる<研究テーマと抱負 $>$ 螢光修飾核酸 プローブによる遺伝子発現モニターシス テムの開発 $<$ 趣味 $>$ 音楽鑑賞, 読書

松本 邦弘 (Kunihiro Matsumoto) 昭 和 26 年 12 月 8 日生 $<$ 略歴 $>1974$ 年大 阪大学工学部醊酵工学科卒業 $/ 1976$ 年 大阪大学大学院工学研究科修士課程修了 ／1977 年鳥取大学工学部工業化学科助 手 $/ 1985$ 年米国 DNAX 分子生物研究所 主任研究員 $/ 1990$ 年名古屋大学理学部 分子生物学科教授，現在にいたる. 1982 年工博 $<$ 研究テーマと抱負 $>$ 癌関連遺伝 子による細胞の増殖・分化の制御機構 く趣味>ジャズ

水野 雅史 (Masashi Mizuno) 昭和 34 年 1 月 21 日生 <略歴> 1984 年神戸大学 農学部農芸化学科卒業 / 1986 年同大学 大学院農学研究科農芸化学専攻修士課 程修了／1989 年同大学大学院自然科学 研究科資源生物科学専攻博士課程修了 (学術博) /同年同大学大学院自然科学研 究科助手 / 1990 年同大学農学部助手／ 1995 年同大学大学院自然科学研究科助 教授 / 2003 年同大学農学部助教授, 現在 にいたる。この間, 1993〜95 年米国カリ フォルニア大学バークレー校博士研究員 （うち 1993〜94 年文部省在外研究員とし て）<研究テーマと抱負>ストレス応答 時に発生する活性酸素種とその防御機構 におけるミトコンドリアの関係を解明し たいく趣味〉動物クリスタル収集, お酒 （特に日本酒）
村上 章 (Akira Murakami) 昭和 24 年 8 月 25 日生 $<$ 略歴 $>$ 昭和 48 年京都大 学工学部石油化学科卒業後, 米国ジョン ズホプキンス大学公衆衛生学部博士研究 員，(株)島津製作所勤務，京都工芸繊維 大学繊維学部助教授を経て, 現在, 同教 授＜研究テーマと抱負＞アンチセンス法 による遺伝子制御，螢光核酸プローブに よる遺伝子機能解析

姚 楠（Yao Nan）昭和 41 年 9 月 12 日生＜略歴> 1988 年北京農業大学農学 部植物保護学科卒業/1997 年神戸大学 大学院自然科学研究科博士前期課程修了 $/ 2002$ 年同博士後期課程修了 (農博) / 同年米国シカゴ大学分子遺伝学・細胞生 物学科研究員, 現在にいたるく研究テー マと抱負 > 植物のプログラム細胞死の誘 導機構 $<$ 趣味 $>$ 音楽鑑賞, 山登り

渡邊 秀典 (Hidenori Watanabe) 昭 和 34 年 7 月 23 日生 $<$ 略歴>昭和 58 年 東京大学農学部農芸化学科卒業 / 63 年 同大学大学院農学系研究科博士課程修了 後, 日本学術振興会特別研究員を経て, 同大学大学院農学生命科学研究科助手／ 平成 6 年同助教授，現在にいたる。この 間，平成 10 年英国ケンブリッジ大学客 員研究員<研究テーマと抱負 $>$ 生物活性 天然有機物合成を専門としているが，作 る「もの」と「つくりかた」の両方で人 に感動を与えられるような仕事がしたい $<$ 趣味>料理, 庭仕事 